\title{
ŚWIĘTO BOŻEGO NARODZENIA
}

„,...Zbliża się święto, spomiędzy wszystkich szczególnie zasługujące na cześć i uwielbienie, które bez przesady można nazwać matką wszystkich swiąt. Jakież to mianowicie? Chrystusowe według ciała narodzenie. Od niego to bowiem biorą początek i uzasadnienie i święto Objawienia Bożego, to jest święto Epifanii, i święto Wielkanocy, Wniebowstąpienia i Zielone Swiątki... Jednak nie tylko z tego względu godzi się dzień ten przenieść nad wszystkie inne; i dlatego również, że to, co zdarzyło się weń, większy niż wszystko linne budzi podziw it cześć. Ze Chrystus, przyjąwszy naturę ludzką, umari, chocỉaż żadnego grzechu nie popełnił, czyż mogło to dodać coś więcej do tamtego cudu? Przyjął bowiem ciało śmierci podległe. A jeśli i to (śmierć) było niezwykłe, to cóż dopiero, że będąc Bogiem, zechciał stać się człowiekíem i nie uw̌ażał sobie za ujmę tak nisko zejść, że nie próbuj tego pojąc rozumem - to jest najbardziej podziwienia godne, pełne przerażającej powagi...

...Dlatego to w szczególnliejszy sposób wyciągam ręce ku temu dniowi i kocham ga 1 miłość swą dla niego otwarcie wyznaję, by was zachęcić do udziału w tym chwytającym za serce święcie. I $x$ tą myślą kieruję do was tę próbę i te zaklęcia, byśdie z całą ochotą i gorliwością, pozostawiając swe domy pustką, chcieli stawić się tutaj, by oglądać naszègo Pana w kolebce, spowiltego w pieluszki... Czymże się wymówimy, jakżeż możemy spodziewać się przebáczenia, jeśli, gdy On dla nas zstąpił z nieba, ociągamy się pośpieszyć doń...(1)

Tak przemawiał św. Jan Chryzostom w Antiochii w dniu 20-go grudnia 388 (może 387) roku. Zbliżająca się urocżystość Bożego Narodzenia nie zdobyła sobie jeszcze wtedy należytego miejsca ani w kalendarzu kościoła antiocheńskiego, ani w sercach wiernych tego míasta. Potrzeba było złotego słowa uwielbianego kaznodziei, by uznano je za święto wielkie i jako taktie święcono.

Więcej jeszcze $z$ dziejów tego święta dowiadujemy się z kazania wygłoszonego w samą uroczystość... ,Już od dawna pragnąłem przeżyć ten dzień, ale nie sam tylko, lecz w talk wi'elkiej liczbie, w jakiej teraz tu jesteście; i prágnąłem oglądać naszą świątynię talk zapełnioną, jak teraz, ją widzę. Pragnieniu memu stało się zadość. I jeszcze nie ma dziesięciu lat, jak dzień ten zawitał do nas. Dzięki jednak

1) Sw. Jan Chryzostom, Oratio de beato Philogonio; Antwerpia 1614. 1. III. str. 388 . 
waszej gorliwosci tak stał się radosnym i uroczystym, jak gdyby od lat tradycyjnie był u nas obchodzony. Słusznie można uroczystość tę nazwać świętem nowym, a równocześnie dawnym. Nowym, bo dopiero poznaliśmy je, dawnym, bo szybko dorównało najpierwszym i osiągnęlo tę samą powagę wieku... Jak szlachetne nasiona, zaledwỉe je zakopiesz do ziemi, już wystrzelają na znaczną wysokość i wydają owoce, tak li ta uroczystość, od dawna znana na Zachodzie, a do nas dopiero teraz przed niewielu laty przyniesiona, tak od razu stała się wielką it wydała owoc, który teraz można oglądać, gdy nasze krużganki są przepełnione a w samej świątyni panuje śdisk z powodu wielkiego napływu... ...Wiem dobrze, że jeszcze teraz wielu spiera się o ten dzỉeń; ci atakują, tamci go bronią. Dużo już powiedziano na temat dzisiejszej uroczystości; zarzuca się jej, że jest świeżo wprowadzona i trąci nowatorstwem... Dzień ten jest jednak tym, w którym narodził się Pan nasz Jezus Chrystus, Bóg - Słowo. ...Chrystus narodzil się w czasie pierwszego spisu ludności. Kto by chciał, może otworzyć stare, do publicznego użytku wystawione księgi w Rzymie i z nich dowiedzieć się dokładnie o dacie tego spísu. $\mathrm{Na}$ co slię to przyda nam, powie ktoś, którzy tam nie mieszkamy i nigdy tam nile byliśmy? Przyjm do wíadomości i daj się przekonać, że święto to przyjęliśmy od ludzi, których dokkadnie o tym pouczono i w tym mieście mieszkają. Ci bowiem, którzy tam znajdują się i od dawna obchodzą je uroczyścîe na podstawie starej tradycji, przesyłają teraz do nas o nim wiadomość..."(2).

Ze od dawna i na podstawie starej tradycji obchodzono to swięto w Rzymie, jest jednak retoryczną przesadą lub osobistym przekonaniem św. Chryzostoma. I tu historia tego święta nîe cofa się wiele ponad trzydziestolecie. Wiadomości bowiem, jakie podaje Liber pontifícalis (3), jakoby już papież Telesfor I (125-136) polecił odprawiać msze św. o północy uroczystości Bożego Narodzenia, są włączone do tekstu pontyfikału, jak wykazały badania, dopiero w wieku V. Nie jest przekonywującym również dowód, jakim posługuje się Leclercq (4), twilerdząc, że święto istniało już przed rokiem 336. Powołuje się mianowicie na spis dat śmierci papieży, sporządzony w wyżej wymienilonym roku. Zestawienie to rozpoczyna zmarły 27 grudnia papież Dionizy; następni zamieszczeni sa

2) Sw. Chryzostom, Homilia in Salvatoris natalem, Antw., t. VI. 26. $7 \mathrm{n}$.

3) Wyd. Duchesne, t. I, str. 129.

4) Dict. d'Arch. chr., t. XII, kol. $912 \mathrm{nn}$. 
według 'miesięcy swej śmiercí. Dwaj ostatni, Marek († 336) i Juliusz († 352) mieli być, zdaniem tego autora, dopisani później bez uwzględniania uprzednilo zachowywanego porządlku. Na podstawie porządku zastosowanego w spisie utrzymuje, że wtedy rok rozpoczynał się 25 grudnia w uroczystość Bożego Narodzenia. Duchesne jest zdania, że daty ustanowienia tegó święta należy szukać na przestrzenî 93 lat (234-336) (5).

Plierwszą pewną wiadomość o istnieniu święta Bożego Narodzenia w dniu 25 grudnia podaje „Kronikarz rzymski“; autorem jego jest Filocalus, późniejszy kaligraf pap. Damazego I. W spisie sporządzonym w r. 354 obok wykazu konsulów i katalogu papieży zamieścił wykaz dní śmierci biskupów i męczenników. I tutaj pod datą 25 grudnia zapisał, „Natus Christus in Betleem Iudae" (6). Dokument ten jest najprawdopodobniej odpisem ówczesnych oficjalnych dyptychów kościoła rzymskiego i jest dow̄odem jego pralktyki̊ w tym czasie.

Cenne uzupełnlienie do tej notatki znajduje się w III księdze „De virginibus“ św. Ambrożego. Przytacza tam (7) św. Doktor ustęp przemówienia pap. Liberiusza (352-366), wygłoszonego przy ceremonii włożenia welonu na jego siostrę Marcelinę. Ceremonila ta mỉała miejsce w dniu narodzenia, jakk wyraźnie podkreślił papỉeż. Ale obok tej pamiątkil wymienił i inne zdarzenia $z$ życỉa Pana Jezusa, jak: cud w Kanie, nakarmieníe czterech tysięcy na puszczy, te właśnie, których pamiątkę obok chrztu w Jordanie i narodzenia obchodzono przed ustanowieniem osobnego świlęta w dniu 25 grudnia, w święto Epifanili dnia 6 stycznia. Ceremonia ta więc odbyła się w tymże dn u w r. 353 (Liberifusz został wybrany 352), gdy nie obchodzono jeszcze osobnej uroczystości narodzenia Chrystusa. Na tej podstawie dochodzı̊my do wniosku, że w r. 354 uroczystość Bożego Narodzenia w dn u 25 grudnia została po raz pierwszy umieszczona w kalendarzu kościoła rzymskilego (8).

Ciekawą jest rzeczą, co zadecydowało, że urocżystość Bożego Narodzenia wyznaczono na ten wlaśnie dzień?

Ani Ewangelie ani tradycja níe pozostawiły żadnych co do tego wsikazówek. Pierwszé generacje chrześcijaństwa całą swą uwagę

5) Bull. critique, 1890 , str. 45 .

6) Wyd. Mommsen w Abh. der sächs. Gesellsch., t. I (1850), 631.

7) Sw. Ambroży, De virginibus III, t. II, str. 173.

8) Usener, Das Weinachtsfest, Bonn 1911, str. $273 \mathrm{nn}$. 
i pobożność skjjlerowały na fakt zwycięstwa Chrystusa nad śmiercią, na Jego zmartwychwstanie, a następnie na zdarzenía, które je poprzedziły, jak męka i śmierć, lub były dalszym ciągiem Jego triumfu, jak wniebowstąpienile i zesłanỉe Ducha Swiętego. W wieku III niemal we wszystkich kościołach przyjęło się nowe święto Pańskie, stojące poza cyklem paschalnym, Objawienie Pańskie - Epífania, obchodzone początkowo w różnych dniach stycznia, potem wszędzie tylko 6 stycznia. Liturgia tego dnia uwzględniała kilka zdarzeń z życîa Jezusa; chrzest w Jordanie, cud w Kanie, rozmnożenie chleba, potem samo narodzenie i pokłon mędrców. Podstawą do utożsamienía dnia narodzenia $\mathrm{z}$ dniem chrztu było zbyt dosłowne zrozumienie tekstu św. Łukasza $(3,23)$ - „Sam zaś Jezus rozpoczynając, był w latach około trzydziestu". W wieku III dartę urodzenia, którą w tym czasie częściej się zajmowano, próbowano ustalić w inny sposób - w zależności od daty śmierci. Opierając się na przypuszczeniu, że w życiu Pana Jezusa wszystko musiało być dokładne i zupełne, twierdzono, że dzień śmiercî był równocześnlle dniem urodzenia. Takiego zdania jest autor traktatu „De pascha computus“ (9), napisanego w r. 243 (przypisywanego św. Cyprianowi), gdzie narodzenie Chrystusa ustala na dzień 28 marca. Że nie zawsze poważnie wyglądały takllie badanía i ich wyniki, dowodzi nagana udzielona przez Klemensa Aleks. już w pierwszych latach III w. takim ultradokładnym historykom (10). Ważnym przyczynklem do ustalenia dziejów tego święta zdawał s'ę być odkryty w r. 1885 w klasztorze greckim w Chalkis rękopis, zarwierający komentarz św. Hîpolita do księgi Daniela (ok. 202 r.) (11). Znalazła đię tam wiadomość, że Chrystus narodził się w środę, dnia 25 grudnia. Wnet jednak stwilerdzono rozmyślną zmianę tekstu i udowodniono, że zdaníem św. Hipolita narodzenie miało miejsce 2-go kwietnia.

Sw. Jan Chryzostom w dalszym ciagu przytoczonego na początku kazanlia udowadnia swym słuchaczom, że data 25 grudnia jest prawdziwą datą narodzenia Chrystusa Pana. Wyliczono ją na podstawie kalendarza żydowskłego. Zachariasz w dzień pojednania (koniec września) w czasie pobytu w miejscu Sw:lętym Swiętych otrzymał zapowiedź narodzenia się św. Jana. W sześć miesięcy potem, a więc w ostatnich dniach marca, dopełnilła się misja anielska

9) Sw. Cyprian, Opera, wyd. Hartel, t. III, str. 267.

10) Klemens Al., Stromata, I, r. XXI.

11) Wyd. Bonwetsch, Hippolyts Werke, t. I, Lipsk 1897. 
w Nazarecie i poczęcie Chrystusa, a na koniec grudnia przypadło Jego narodzenie. Dowodzenie to jest błędne od początku, gdyż Zachariasz nie był arcykapłanem, a wildzenie miało miejsce przy ołtarzu kadzenia w czasie, który z braku bliższych danych, nie sposób określić. Nie zawdzięcza ono swego powstania tylko fantazji swiętego Chryzostoma. Tego zdanila miał być i św. Ambroży i Augustyn, a nawet św. Hieronim (12). Żródłem tych wiadomości miało być jakies „,pismo Hebrejczyków“, na które powołuje się ten ostatni (jeśli jego rzeczywiście jest ta homilîa) (13) i apokryficzny list pap. Juliusza I do Cyryla Jer. (14). Swięto Zwiastowania powstało znacznie później i w zależności od 25 grudnia, a nie odwrotnie.

Leclercq jest zdanila, że powodem wybrania daty 25 grudnia były względy symboliczno-astronomiczne. Dzień ten w kalendarzu rzymskim był datą zimowego przesilenlia. A ponieważ Chrystus był nazywany słońcem (Mal. 4, 2; Łk. 2, 32; św. Cyprian nazywa Go „Sol verus et dies verus“), które w tym dniu zwycięża il odradza się, dlatego dzień ten wybrano jako najstosowniejszy dla uczczenia narodzenia Chrystusa „słońca sprawiedliwości“ (15).

Rozwiązanie powyższe, nie jest przekonywujące jednak mimo swej trafnoścî. Względy te mogły odegrać pewną rolę, ale zasadniczą była najprawdopodobniej inna okoliczność.

Już w wieku II pod wpływem religili Wschodu zaczą przenikáć do Italii kult boga-słonca. Całkowite prawo obywatelstwa zdobył sobie w wieku III, zwłaszcza dzięki poparciu 'cesarza Heliogabala (218-222). Ku çci boga-słońca już dość wcześnîe w dniu zimowego przesilenia, a raczej w nocy $24-25$ grudnila zaczęto urządzać uroczyste pochody z płonącymỉ pochodniamij. Uroczystą nazwą tego święta słonecznego bylo ,Natalis Invicti" sc. solis. W tych uroczystościach, bardzo zresztą urozmaiconych i pociągających, dających jednak okazję do wielu zgorszeń, úczestniczyli także chrześcijanie. Taki udział nlie przynosił bynajmniej pożytku chrześcijaństwu, sam jednak tylko zakaz wydany przez biskupa nie miał widoków powodzenia. Przeciwstawił więc papỉeż Liberiusz chrześcijańską uroczystość pogańskim obchodom, pozwalając wprowadzić do niej przyjęte w tym dniu zwyczaje palenia ognil i procesji z pochodniami. Porównania Chrystusa do słońca, którego kult tkwił jeszcze w pa-

12) Dict., kol. 920.

13) Dict., kol. 919.

14) Dict., kol. 910, 919 .

15) Dict., kol. 914, 915. 
mięci wiernych, były bardzo aktualne i kanonizowały do pewnego stopnia pozostałoścî zwyczajów pogańskich.

Okoliczność ta jednak nie nadawała się do popularyzowania tego swięta. Owszem była powodem zarzutów przeciwników. I tak manichejczyk Faustus zarzuca św. Augustynowi: „Wy obchodzicie pogańskie uroczystości z ich noworocznymi ì słonecznymi obchodami". Odpowiedź była prosta i zgodna z prawdą. "My czcỉmy tego, który jest wię̨kszy, niż słońce“ (16). Dlatego pomijano tę okoliczność przy omawianiu tego święta, owszem polemizowano z nim i zbijano twierdzenie, że kościół obchodzi nie tyle narodzeníe Chrystusa, jak narodziny nowego słońca (17). Przekonanie, że data 25 grudnia była świadomą chęcią przeciwstawienia chrześcijańskiej uroczystości świętu pogańskiemu, sięgnęła aż na Wschód, gdzie dał temu wyraz w kilka wieków potem komentator dzieł Dionizego bar Salibi w swym dopisku na marginesie: „Podają, że powodem, dla którego przeniesiono wspominaną przez Ojców uroczystość ze stycznia na grudzien, jest fakt następujacy: Poganie w tym dniu obchodzili uroczyście święto narodzenia słońca... weszło w zwyczaj, że do tych obrzędów zapraszano i dopuszczano także chrześcijan... Postanowiono tedy w tym dniu obchodzić święto narodzin Prawdy, w dniu zaś 6 stycznia polecono obchodzić Epifanię" (18). Okoliczność ta jednak, którą niektórzy Ojcowie zdają się skrzętnie ukrywać, w niczym nie ubliżała wprowadzonemu świętu, które przez swój charakter stało się jednym z najmilszych świąt chrześcijaństwa. W ciagu stulecia zostało wprowadzone do wszystkich niemal prowincji kościelnych, spotykając się z takim przyjęciem, jakie widzieliśmy $u$ św. Chryzostoma. Jedną

$z$ opornych pod tym względem była przez pewien czas - rzecz dziwna - Jerozolima i Betlejem. Ale i tam 25 grudnia stał się dniem uroczystym przed r. 439 za rządów patriarchy Juwenalisa. Jedynie Armenia wprowadziła u siebie tẹ uroczystość dopiero w w. XIV.

\section{O. AUGUSTYN CHADAM.}

16) Sw. Augustyn, Contra Faustum XX 4.

17). Sw. Leon, Sermo XXII, 6.

18) Assemani, Bibliotheca orientalis. t. II, str. 164. 